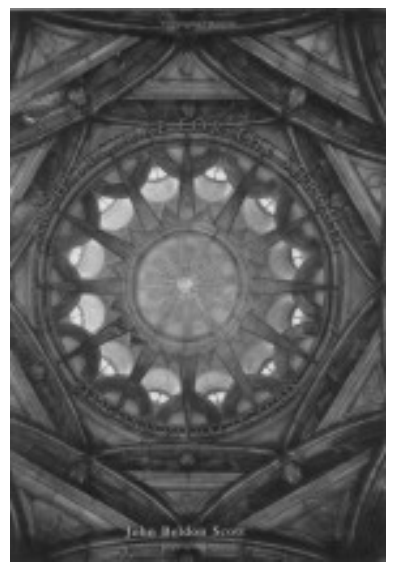

\title{
John Beldon Scott \\ Architecture for the Shroud: Relic and Ritual in Turin
}

\author{
University of Chicago Press, 2003
}

Reviewed by James McQuillan

\section{Saga of the Holy Shroud}

The saga of the Holy Shroud is perhaps the most intriguing tale of piety and dynastic fortune in the second millennium of Christianity. This length of linen came into the hands of the Dukes of Savoy, who used it as their family guarantee of divine election and carried it to their new Italian capital of Piedmont, the city of Turin, which they subdued in 1576. Both Shroud and City have been linked ever since, and John Belton Scott tells the full story of the Shroud from when it was kept in the Sainte Chapelle in Chambery to its eventual resting place in the Turin Royal Chapel, situated between the Palace and the Cathedral of St John, but accessible and visible in its casket by the faithful from the nave of the Cathedral (though not any more, since the great fire of 1997). Professor Scott celebrates the identity of the Shroud as the only undivided and integral icon of the Passion and Entombment of Christ, and furthermore finds sources for the form of the Chapel in Turin in the overall history of the valued treasure and the piety surrounding it. Thus he is perhaps the first to render this total and complex history within the covers of one book and deserves our thanks for this worthy and comprehensive task, as he has treated all the 'ostensions'-ritual displays — of the Shroud up to the present.

This great theme encompasses another extraordinary event: the actual design and construction of the Royal Chapel itself. The Dukes claimed the Kingdom of Jerusalem by marriage, and possession of the Shroud was yet another justification for claiming the Holy Land. Impelled by so much piety and regal pretension, in 1666 Duke Carlo Emanuele II called on the scholar-priest Guarino Guarini, at the time the most egregious member of the elite Order of Clerks Regular, or Theatines, to cover the circular space already laid out for the Shrine years before. Professor Scott believes that the meaning of the resulting complexity is found in the ritualistic and iconographical traditions surrounding the Shroud itself, and to a certain extent he is right. Indeed he covers the ground laid out in the literature and then adds some excellent discoveries of his own-most importantly the application of the flower of the passion vine, found in Brazil and then cultivated and extolled in Italy, in the detailed treatment of capitals, and other factors-drawn from the period that make every sense. It is the personality of this important figure, Father Guarini, which remains the final conundrum at the heart of this unique tale of ritual explanation and visual exegesis. 
Architectural scholars are now agreed that Guarini is of one of the great figures of High Baroque, with Bernini and Borromini-when these were at the height of their powers Guarini was in Rome for his novitiate. Professor Scott celebrates the intellectual command of the Theatine scholar-Guarini published tomes on philosophy, mathematics and astronomy-over such processes as perspective manipulation of the overall design of the uppermost part of the Chapel's dome and the iconographic meaning arising out of the coffering of the pendentive zone. But was Guarini, as Scott claims, 'original' (p. xxi)? This is indeed a modern qualification, to a great extent the most important qualification leading to the recognition of genius today. Guarini's involvement with his age was complete, but he would not have thought of himself as 'original'. As a philosopher of Second Scholastic living in the post-Galilean age, he was assiduously mindful of every authority; only rarely did he breach the boundaries of established learning, and then with fulsome justification. Indeed the achievement of Guarini is the last great statement of universal mimesis in European art and architecture, a statement that is traditional above all. Professor Scott seems not to share such a judgment, unable to proceed beyond the purported illusionism of the upper dome.

Guarini was an adept of many disciplines-including philosophy, scholastic physics (not the mathematico-physics of the contemporary Paris school), and, of course, mathematics - but he was also a contemplative and, for him, the visual arts made poor starting points for access to wisdom and divine union. To belabour his 'originality' is to render the Theatine a disservice, and we must be careful to make that effort to approach him without such contemporary blinkers. Professor Scott's contribution will be the standard work on the history of the Shroud in its European context, but Father Guarini's abilities and the achievement in all his work still require refined consideration. Scott does not venture into any profound description of Guarini's mathematics (his Universal Mathematics and his 'proportional projection'), thus avoiding the findings of scholars that he claims to understand. His application of an equilateral triangle to the profile of the upper dome is surely his weakest interpretation, where the application of the hyperbola in terms of angelic illumination would seem to be much more probable. That this should be so is justified by his command of the geometry of conics and his attachment to divine illumination, both extensively documented in his magisterial publications on mathematics and metaphysics respectively.

The destruction of the interior of Guarini's Chapel is the saddest blow that impedes the glorification of Europe's most singular architect, and our generation may be condemned to read about his work only, just when his meaning might be more fully revealed. Let us hope that the restoration of the dome after the 1997 fire will provide us again with the spectacle of the greatest expression of refined architecture that Europe has ever produced, and triumph of the High Baroque.

\section{About the reviewer}

James McQuillan is an architect and theoretician who spent a considerable time in practice spanning 1969 to 1982, which also saw periods in academia, acquiring an MA under Prof. Joseph Rykwert at the University of Essex, and spending a research year in Rome. In that period he was involved in conservation and leisure architecture as well as teaching at his old school of architecture in Dublin, and practising on his own account after 1978. In 1982 he returned to academia full-time, first by teaching in Arabia for four years and travelling in Europe. He completed his doctoral thesis on Guarini in 1991 at the University of Cambridge under Dr. Dalibor Vesely, and has conducted an international career of teaching and research in architecture and the humanities until the present. He is currently B. Arch. Course Leader at the University of Botswana, in Gaborone, and a member of both the British and Irish Royal Institutes of architecture. 